\title{
CONSTITUTIVE AND DEPICTIVE CREATIVITIES IN PHILOSOPHY AND CRITICAL THINKING
}

\author{
Huiyuhl YI* \\ Ulsan National Institute of Science and Technology, Division of General Studies, 50 UNIST-gil, \\ Eonyang-eup, Ulju-gun, Ulsan 44919, South Korea
}

Received 10 September 2017; accepted 27 February 2018

\begin{abstract}
This paper expounds two types of creativities in philosophy while exploring several influential philosophical views and thought experiments. The two types of creativities include constitutive creativity and depictive creativity. Constitutive creativity refers to the capabilities required for constructing theoretical equipment or tools needed to constitute the core of a given philosophical thought. It can be assessed in terms of the appropriateness of the theoretical apparatuses used in the target idea. The embodiment of constitutive creativity is often coupled with depictive creativity. Depictive creativity refers to the abilities to cite striking examples or build narratives that support the issue at hand. The assessment of depictive creativity depends on the ingenuity of the examples or stories insofar as they positively contribute to the establishment of the desired conclusion. While elucidating the notions of constitutive and depictive creativities by examining several examples in the literature of philosophy, I highlight that critical thinking operates as the cornerstone on top of which both types of creativities may be built.
\end{abstract}

Keywords: conceivability argument, consequence argument, constitutive creativity, depictive creativity, knowledge argument, violinist case.

\section{Introduction}

Similar to performing many other tasks, doing philosophy is a creative activity. Since philosophy, by its nature, engages in a critical analysis of the subject matter, the type of creativity involved in philosophy has certain features characteristic of critical thinking. This paper examines the nature of creativity that is typical of philosophy while investigating several influential views and thought experiments in philosophy. In particular, I explain constitutive and depictive creativities that are used to establish philosophical views. I illustrate how these two types of creativities are embodied in philosophical texts, scrutinizing central arguments in several areas of philosophy such as metaphysics, epistemology, philosophy of mind, and ethics. This task will help us see various ways in which constitutive and depictive creativities can be realized.

${ }^{\star}$ Corresponding author. E-mail: huiyuhl@unist.ac.kr 
In doing so, I contend that the ability to reason and think critically is vital to demonstrate the two types of creativities. People may think that critical thinking is not easily paired with creativity for several reasons. For instance, it may be argued that critical reasoning is essentially a rule-following activity, which curtails the originality and inventiveness of thought. I believe that this claim is misguided. First of all, a certain valid line of reasoning works effectively not because it merely follows the appropriate rules but because the rules themselves correspond to our reason. For example, consider the rule of modus tollens and a famous invalid form known as denying the antecedent. People sometimes make an erroneous reasoning of the form "p $\rightarrow$ q. $\sim$ p. . $\sim$ q", as instantiated by the following argument: "If Paul got into a car accident, he will be at the hospital. He didn't get into a car accident. So, he is not at the hospital". Of course, this is fallacious. Paul could still be in the hospital for a different reason. Our reason tells us that the premises are insufficient for establishing the conclusion. In contrast, any argument instantiating the form "p $\rightarrow$ q. $\sim$ q. $\therefore \sim$ p" is valid. This is because modus tollens fully accords with our reason. Second, there is no reason to assume that a rulefollowing activity lacks creativity. In fact, insofar as mapping out a strategy requires some sort of creativity, following rules may enhance one's creativity in applying them; this is true of many cleverly designed board games such as chess or weiqi. This point is further evidenced by ingenious valid arguments that I discuss later in this paper.

It may also be believed that, similar to the axioms of mathematics, the foundations of critical thinking are so stringently defined that in making an argument from a set of wellestablished judgments, the rest of the inference is merely a mechanical procedure that hardly allows room for creative endeavor. However, from a logical perspective, making a move from a cluster of premises for the justification of the desired conclusion may require a considerable amount of ingenuity. There may be some protocol or "rules of thumb" that one would follow to infer the conclusion from the given premises. However, devising such procedural equipment should be regarded as a work of art, as a random thought certainly would not lead anywhere close to the desired conclusion.

Therefore, the previous objection seems to be mistaken because it hinges on a fairly narrow conception of creativity. Simultaneously, however, it divulges a need for clarifying the notion of creativity that is discussed in this paper. In what follows, I first explain the meaning of constitutive and depictive creativities. Thereafter, I discuss some seminal arguments in philosophy to demonstrate how the two types of creativities are employed in constructing central works of philosophy. The analysis of the structure of each argument makes it clear that the ability to apply critical thinking is a crucial part of manifesting the two types of creativities. Critical thinking, as it were, is the cornerstone of the two creativities.

Much interesting work on creativity has been published in the literature of psychology and philosophy. From the perspective of psychology, among the seminal works include the investigation of what kinds of psychological character traits creative people tend to exhibit (Locher, 2010; Feist, 2002; Simonton, 2010; Amabile, 1996), whether and how creativity is associated with some form of irrationality (Elster, 2000; Baumeister, Schmeichel, \& DeWall, 2014; Simonton, 1999, pp. 94-104), and whether the evolutionist approach to creativity plausibly explains the phenomena in the psychology of creativity (Campbell, 
1960; Gabora \& Kaufman, 2010; Simonton, 2009; Picciuto \& Carruthers, 2014; Dutton, 2001; Briskman, 2009). ${ }^{1}$

Though the contemporary philosophical debate on creativity is relatively thin, there have been some interesting discussions (see Paul \& Kaufman, 2014; Gaut, 2010; Gaut \& Livingston, 2003 for useful surveys of recent philosophical work on creativity). Presumably, the most fundamental issue has to do with the concept of creativity itself. Philosophers, wondering precisely of what creativity consists, generally agree that creativity involves originality and value: a creative product must be both novel and worthwhile. Nevertheless, this dual condition has sometimes been challenged (Boden, 2004; Novitz, 1999; Stokes, 2011; Runco, 2010). ${ }^{2}$ Philosophers have also asked whether creativity can be a computational process: can a purely computational system, such as artificial intelligence, or a mechanical process, such as computer-based data processing, realize creativity in the genuine sense? Boden answers in the affirmative. For example, she claims that inventive ways of combining pre-existing ideas amount to what can be termed combinational creativity (Boden, 2004, pp. 3-10). ${ }^{3}$ By contrast, others argue that a computational system cannot demonstrate understanding (Searle, 1980); if creativity requires some type of understanding, this means that creative activities cannot be performed by a computational system in the classical sense. Another important philosophical debate on creativity concerns whether creativity is domain-specific. Does the creativity displayed in fine arts and music differ from that in science and the humanities? Some thinkers hold that creativity works in a similar fashion in both domains (Weisberg, 2006, pp. 1-58; Briskman, 2009), especially because they both involve problemsolving processes. Others oppose this view, denying that the creation of art is particularly characterized by problem solving (Dutton, 2001; Leddy, 1990, see also Baer, 2010; Sawyer, 2012, pp. 297-386 for useful empirical findings on this issue).

All aspects of this discussion, in some way or another, concern the fundamental features of creativity itself. This paper, by contrast, articulates the nature of the creativity involved in philosophy. For this reason, this paper will be purely descriptive. I will not try to defend or oppose any particular position concerning the issues related to the philosophical views discussed here. Accordingly, this paper should be of interest not only to philosophers but also to anyone who would like to reflect on what types of creativities are involved in philosophy and how they are shaped in constructing philosophical arguments.

\footnotetext{
1 The evolutionist approach holds that human creativity is the product of evolutionary processes such as natural selection both in the context of the biological evolution of human species and the cultural evolution of ideas. This approach has been dominant in psychology (for alternative approaches to creativity, see Ward \& Kolomyts, 2010; Feist, 2010; Locher, 2010; Puccio \& Cabra, 2010; Simonton, 2010; Richards, 2010; Kaufman, Kornilov, Bristol, Tan \& Grigorenko, 2010; Russ \& Fiorelli, 2010; Smith, J. K. \& Smith, L. F., 2010; Lubart, 2010; Gabora \& Kaufman, 2010; Cropley, D. \& Cropley, A., 2010).

2 The concept of the dual condition for creativity is usually attributed to Immanuel Kant, who argued that the product of a genius must be "exemplary" (2000, pp. 186-187). Margaret Boden and David Novitz argue that a creative work must be surprising in addition to the two conditions, whereas Dustin Stokes and Mark Runco maintain that the value condition is not necessary.

3 In a later work, Boden (2014) concedes that the "real" creativity may involve autonomy, intentionality, and consciousness (construed broadly to include emotion and valuation). However, she argues, since we lack deep understandings about these qualities, the previous concession does not lead to the conclusion that artificial intelligence contradicts creativity.
} 


\section{Constitutive and depictive creativities expounded}

The core of a philosophical view is usually given in the form of an argument. The conclusion of an argument is the main claim that one wants to establish by presenting the argument. ${ }^{4}$ Then, when one proposes a philosophical view, the goal is to provide a powerfully and rigorously supported argument that even an opponent would have to endorse it. ${ }^{5}$ In this respect, it is essential to devise strategical apparatuses supporting the target conclusion convincingly. Constitutive creativity involves the abilities required to develop or employ viable theoretical tools such as thought experiments and logical principles in setting up an argument.

There are several criteria for evaluating the appropriateness of the theoretical equipment produced through constitutive creativity. First, the apparatuses should cohere with the claims the argument aims to establish. A philosophical argument may comprise several sub-arguments; often, the ingenuity of the argument depends on some of the crucial moves used in developing the sub-arguments. The theoretical apparatuses should be conducive in presenting the important steps that lead to the conclusions of those sub-arguments. In other words, they are a means to enhance the coherence of the argument.

Second, the apparatuses should increase the clarity of the argument. Readers of philosophical arguments are often invited to follow intricate trails of thought. Since they can easily become lost in the maze of complexity and subtlety, presenting the argument as clear as possible is important. Although clarity is sometimes considered to be merely a matter of the author's writing style, an ingenious theoretical tool can fundamentally affect the manner in which we think. David Lewis' analysis of counterfactuals is a good example. It demonstrates how we can understand modality and truth in terms of possible world semantics (see his magnum opus (Lewis, 2003) for a full-fledged exposition of the possible world semantics wherein he defends modal realism).

Third, the theoretical tools ought to be devised efficiently as they are directly relevant for reaching the conclusion or for determining what is necessary to deduce the conclusion. In other words, the apparatuses should not be redundant in setting up an argument. Each element of an argument should precisely demonstrate what it is supposed to achieve, and when gathered, the elements should substantiate the argument as an organized whole. Accordingly, the author can draw a lesson from Occam's razor, which advises us to choose a hypothesis with less theoretical equipment among competing ones, if other things are equal.

The previous observation indicates that the demonstration of constitutive creativity requires certain qualities such as coherence, clarity, and efficiency. To develop theoretical tools

\footnotetext{
4 In standard understanding, an argument comprises premises and a conclusion, where the premises are supposed to support or provide the reasons to believe the conclusion. This notion of an argument applies to a host of disciplines besides philosophy. For example, an empirical scientific discovery can be given in the form of an argument. In this case, typically, the data obtained from systematic observations may be considered premises; if they vindicate the hypothesis being tested, the vindicated hypothesis may be put forward as the conclusion. Even mathematical proofs may be understood as arguments: if a theorem is derived from relevant axioms or other pre-established statements, the whole derivation is an argument that has the theorem as its conclusion and the other parts as the premises.

5 Here, I do not mean to suggest that philosophical argumentation is akin to argumentative rhetoric or sophistry, which merely aims to win over an opponent. In philosophy, an argument is most importantly supposed to function as a means to discover the truth, as well as a means to convince any opponents. Therefore, the arguer is expected to scrutinize their argument as critically as any opponent would do.
} 
that meet these conditions, we should be able to see through the nature of the argument. Once we devise the tools, determining how we can successfully convey the main argument is important. What type of an argument would effectively deliver the main claim? Should we use a rhetorical device such as analogy? If we use a thought experiment, how should we construct its narratives? How should we describe the characters in the narratives? What type of features should they possess to make the narratives compelling and germane to sustain the issue at hand? These are all relevant questions in developing depictive creativity. Depictive creativity, as I shall understand the term, refers to the capabilities required to construct remarkable examples or stories that suitably support the claims sustained by the theoretical apparatuses. Depictive creativity differs from constitutive creativity in that the former pertains to how a given argument is presented, whereas the latter is more relevant to how it is composed.

Depictive creativity works in several ways. For instance, one can make an argument more convincing by providing accounts of events or incidents quite common in everyday life. Hence, sometimes it will be effective to use examples familiar to most readers since ordinariness or familiarity may capture the common forms of life that we share. However, depictive creativity does not always spring from familiarity. In some cases, what is alien to our common experience may increase the memorability of the examples. Striking examples or stories often contain some unexpected elements. The author's ability to express depictive creativity may partly depend on his/her regulation of the familiarity/unfamiliarity of the examples in establishing the argument.

Another way to advance the persuasiveness of the argument has to do with the vividness of the depicted items. The narratives of the examples or stories reflect the logic of the argument at hand. However, the narratives do not merely represent the argumentative aspect of the view. They may also strengthen the readers' understanding of the argument by describing a series of relevant events as illustrative examples. Hence, presenting narratives with picturesque and interesting details is important. The memorability of the depicted items may also be increased by narratives with striking details.

So far, I have expounded the notions of constitutive and depictive creativities in their generality. In the following, I demonstrate how the two types of creativities are embodied in practice by reviewing some of the influential work in philosophy.

\section{Constitutive creativity illustrated}

While illustrating constitutive creativity in philosophy, I would like to analyze a classical argument proposed by René Descartes. Descartes is well known for maintaining substance dualism. In the spirit of distinguishing body and soul, he wrote as follows in the "Second Meditation":

"[...] by a body I understand whatever has a determinable shape and a definable location and can occupy a space in such a way as to exclude any other body; it can be perceived by touch, sight, hearing, taste or smell, and can be moved in various ways, not by itself but by whatever else comes into contact with it" (Descartes, 1984, p. 17).

An object has to be extended in the spatial dimension for it to have a "determinable shape" and a "definable location" and to be perceived by the five senses. Hence, this quotation states that the essential nature of a body is constituted by its quality of being extended. In other words, the Cartesian conception of a body deems spatial extensionality to be essential to the existence 
of a body. Then, what does it mean by saying that some feature is an essential property of an object? The standard understanding of essentiality in philosophy takes the following formulation:

A property $\mathrm{F}$ is essential to an object $\mathrm{O}=d f$

It is logically impossible for $\mathrm{O}$ to lack $\mathrm{F}$ and exist at the same time.

An essential property is a property that an individual must possess to exist - if one loses the property, one would cease to exist. According to Descartes, it is an essential property of a human body and of any physical object for that matter that the body is spatially extended. Later, in the same "Meditation", Descartes claimed that, although this property is essential to the body, it is not essential to the person. To establish this point, Descartes proposed an intriguing thought experiment:

"But what shall I now say that I am, when I am supposing that there is some supremely powerful and [...] malicious deceiver, who is deliberately trying to trick me in every way he can? Can I now assert that I possess even the most insignificant of all the attributes which I have just said belong to the nature of a body? I scrutinize them, think about them, go over them again, but nothing suggests itself [...]" (1984, p. 18).

The aforementioned malicious deceiver is supposed to be an all-powerful being who can fool me in every respect and content. Let us call this being the Evil Genius. As envisaged by Descartes, the Evil Genius can bring forth any kind of unveritable experiences and false beliefs in our minds. It can create a fictitious sense-perception that involves our bodies and the false belief that we possess various types of bodily attributes. In that respect, this thought experiment is comparable to Robert Nozick's famous example of virtual reality. Nozick envisaged that one is hooked up to a fabulous machine that provides whatever pleasant experiences one wishes, except that they are not real (1974, pp. 42-45). ${ }^{6}$ Similarly, one can be systematically and massively misguided by the Evil Genius in one's beliefs and experiences. The Evil Genius is omnipotent in whatever way that God is thought to be, except that he is evil. This entails that it is a genuine logical possibility that I can exist without being spatially extended. To use the possible world semantics, we can state that in some possible worlds where only I and the Evil Genius exist, I may not be spatially extended (and thus may not be sensibly recognized).

From the previous discussion, we can generate what is known as the conceivability argument: ${ }^{7}$

Premise 1. My body has the property of being essentially extended.

Premise 2. I do not have the property of being essentially extended.

Conclusion. I am not identical to my body. ${ }^{8}$

\footnotetext{
6 Though Nozick's experience machine example is analogous to Descartes' Evil Genius thought experiment, they do not aim for the same target. While Nozick's example is usually referred to for the rejection of hedonism, Descartes' thought experiment is often regarded as an argument for substance dualism.

7 This argument is based on the observation that a person's disembodiment is conceivable. One might argue that it is a mistake to infer possibility from conceivability. To adjust Saul Kripke's famous example, though it is conceivable to consider Hesperus and Phosphorus as being non-identical, it is in fact impossible for them to be distinct from each other (1980, pp. 28-29). However, my purpose in citing the conceivability argument does not lie in evaluating it but in showing how it illustrates constitutive creativity.

8 Here, the conclusion is deduced from the premises by Leibniz' law. Leibniz' law is ambiguous between two principles: the principle of the indiscernibility of identicals and the principle of the identity of indiscernibles. What is being employed here, of course, is the former, formulated as: $\forall x \forall y[(x=y) \rightarrow \forall P(P x \leftrightarrow P y)]$, which reads as follows in English: for any $x$ and for any $y$, if $x$ is identical to $y$, then for any property $P$, $x$ has $P$ if and only if $y$ has $P$. The latter is the converse of the former.
} 
This precise argument cogently embodies constitutive creativity. In particular, it utilizes the notion of essentiality and the Evil Genius thought experiment as well-designed conceptual apparatuses. Let us first note that the essentiality notion is effectively used in the two premises because without referring to this notion, I and my body would not be successfully distinguished. It is important to see that a thinking being, e.g., a physically materialized artificial intelligence, can be spatially extended. However, it may still be true that a thinking being need not be spatially extended, as envisaged by Descartes. This reveals that the argument stands only with recourse to the notion of essentiality. The Evil Genius thought experiment is another conceptual tool that plays a central role in the argument. As given in the story, the Evil Genius enables us to conceive a scenario wherein one can exist without one's body while preserving the same kind of mental life as we would have in a real world. This is a crucial step that leads to the conclusion of the conceivability argument. We can note from this observation that the preceding two theoretical apparatuses are suitably designed such that they cohere with the desired conclusion: they adequately support the idea that I and my body are not identical.

The aforementioned theoretical tools meet other criteria for constitutive creativity as well. The core of the conceivability argument is to show how my body can be conceptually differentiated from me, the person. As we can see, what is envisaged in the Evil Genius thought experiment is the circumstance where one's mind operates as it is without being embodied in any material object. The fact that we can consistently conceive this scenario indicates the non-identity of a person and his/her body. The thought experiment is an appropriate means to fulfil the aim of the conceivability argument; it clarifies how the abstract claim that a person and his/her body is not identical can be realized in some realm of possibility. In this respect, the thought experiment enhances the clarity of the argument.

In addition, the theoretical apparatuses play their parts quite efficiently in the argument. To establish the non-identity claim, it must be shown that there is a certain property possessed by only one among the person and his/her body but not by the other. However, one would not be distinguished from one's body by virtue of a non-modal property because one may well be spatially extended in reality. The difference can only be given in terms of modality. Therefore, what differentiates one from one's body - the property of being essentially extended - ought to be a modal property. Since essentiality is a modal notion, the premises of the argument can support the conclusion by referring to the notion of essentiality. The Evil Genius thought experiment illustrates how one can exist without being spatially extended. Hence, it justifies the second premise of the argument. Since the thought experiment directly supports the premise and the essentiality notion is a necessary means to establish the non-identity claim, we can conclude that they meet the efficiency condition for evaluating constitutive creativity.

So far, we have seen that constitutive creativity is salient in Descartes' conceivability argument in terms of coherence, clarity, and efficiency. In what follows, I analyze another influential philosophical argument that I believe typifies constitutive creativity.

Peter van Inwagen famously proposed an argument for the incompatibility of free will and determinism. This argument is known as the consequence argument. His strategy was to show that no one has free will about anything under the assumption that determinism is 
true. To fulfil this aim, van Inwagen invented several conceptual tools. One of them is what he called the operator $\mathrm{N}$, defined as follows:

$\mathrm{N} p={ }_{d f} p$, and no one has, or ever had, any choice about whether $p$ (van Inwagen, 1983, p. 93).

Under this definition, "N All men are mortal" is an abbreviated form of the statement "All men are mortal, and no one has, or ever had, any choice about whether all men are mortal". Van Inwagen also created and introduced a couple of inference rules as follows:

$$
\begin{gathered}
(\alpha) \square p \vdash \mathrm{N} p . \\
(\beta) \mathrm{N}(p \rightarrow q), \mathrm{N} p \vdash \mathrm{N} q .{ }^{9}
\end{gathered}
$$

He believed that the two rules are valid. Rule $(\alpha)$ states that we do not have any choice about what is necessarily true. Since we do not seem to have any power to turn necessary truth into falsehood, this rule seems evident (van Inwagen, 1983, p. 96). In addition, van Inwagen found rule $(\beta)$ utterly plausible while reviewing some instances of $(\beta)$ that seemed to be clearly valid, although he did not provide a conclusive argument for it (1983, pp. 97-99). ${ }^{10}$ After drawing up the two rules, van Inwagen made certain abbreviations. He stipulated that " $\mathrm{P}_{0}$ " denotes the proposition that completely describes the state of affairs in the universe at some arbitrarily chosen time in the past when no human agent ever existed, "L" denotes the conjunctive proposition of all laws of nature, and "P" denotes a dummy proposition that may stand for any ordinary action or decision made by human agent at the present moment (e.g., I am raising my arm now). Given these theoretical tools and abbreviations, the consequence argument can be given as follows. Suppose we assume the truth of determinism. Since determinism is the view that a unique future is necessitated by the past state of affairs and the relevant laws of nature, if determinism is true, then any of our ordinary actions or decisions is necessarily caused by some past events and the laws of nature operating on them. Then, determinism implies the following statement:

$$
\square\left[\left(\mathrm{P}_{0} \& \mathrm{~L}\right) \rightarrow \mathrm{P}\right],
$$

which is equivalent to

$$
\square\left[\mathrm{P}_{0} \rightarrow(\mathrm{L} \rightarrow \mathrm{P})\right] .^{11}
$$

Applying ( $\alpha$ ) to (2), we can derive:

$$
\mathrm{N}\left[\mathrm{P}_{0} \rightarrow(\mathrm{L} \rightarrow \mathrm{P})\right] .
$$

\footnotetext{
9 Here, I follow the convention of logic in using the symbols: $\square, \rightarrow$, and $\vdash$ express the notions of necessity, conditional, and derivability, respectively.

${ }^{10}$ Some commentators maintain that $(\beta)$ is not a valid rule of inference. For example, Thomas J. McKay and David Johnson (1996) indicated that $(\beta)$ entails what is clearly an invalid rule, which is sometimes known as agglomeration: $\mathrm{N} p, \mathrm{~N} q \vdash \mathrm{N}(p \& q$, for other critiques that provide counterexamples to $(\beta)$ (see Widerker, 1987; Carlson, 2000 ). Later, Inwagen (2000, pp. 2-10) acknowledged the invalidity of ( $\beta$ ), and revised it.

${ }^{11}$ Here (2) follows from (1) by applying a modalized version of an equivalence rule in propositional logic. The rule is known as exposition: $(p \& q) \rightarrow r:: p \rightarrow(q \rightarrow r)$.
} 
Since we have no control over any past event that occurred before our existence, we can introduce the following statement as a premise:

$$
\mathrm{NP}_{0}
$$

Then, by applying $(\beta)$ to $(3)$ and (4), we derive:

$$
\mathrm{N}(\mathrm{L} \rightarrow \mathrm{P}) \text {. }
$$

Since we have no control over any law of nature, we can introduce the following statement as another premise:

\section{NL.}

By applying $(\beta)$ to $(5)$ and (6), we derive:

NP.

As P may denote any human action or decision occurring at the present moment, (7) amounts to the denial of free will. Since we are led to the denial of free will under the assumption of determinism, the proof above is an argument for incompatibilism. ${ }^{12}$

Let us note that in the presentation of the consequence argument, van Inwagen appropriately used several theoretical tools such as the operator $\mathrm{N}$ and inference rules $(\alpha)$ and $(\beta)$. These apparatuses successfully display the due qualities for the embodiment of constitutive creativity. The operator $\mathrm{N}$, for instance, is designed to express the notion of certain states of affairs over which we, as human agents, have no control (or, in van Inwagen's terms, the states of affairs that we have no choice about). Given that the notion of control or choice is closely related to the notion of freedom in the free will literature, the operator $\mathrm{N}$ is an indispensable tool for the argument. In addition, we can observe that the main conclusion of the argument is reached via a series of sub-conclusions such as (3) and (5), where $(\alpha)$ and $(\beta)$ are vital to bring forth those sub-conclusions. Then, the two inference rules as well as the operator $\mathrm{N}$ satisfy the coherence condition of constitutive creativity.

Notably, the theoretical apparatuses enhance the clarity of the argument. As an argument for incompatibilism, the consequence argument aims to establish the conditional claim that if determinism is true, then human free will is impossible. With the aid of some logical tools, van Inwagen succinctly captured the ideas of determinism $\left(\square\left[\left(\mathrm{P}_{0} \& \mathrm{~L}\right) \rightarrow \mathrm{P}\right]\right)$ and the impossibility of free will (NP). In particular, the consequence argument is designed to elaborate a rather simple idea that since we cannot control the past or natural laws, we cannot control their consequences either. The operator $\mathrm{N}$ articulates the central premises with utmost clarity, as we can see from (4) and (6), while $(\alpha)$ and $(\beta)$ help us see how the desired conclusion $\mathrm{NP}$ - is derived from the premises.

Finally, when we examine the consequence argument, we can note that each step from (1) to (7) is quite concisely interlocked with those around it so that there is no unnecessary or redundant step in the process. Especially, the two inference rules $(\alpha)$ and $(\beta)$ precisely deliver what are needed in the central portions of the derivation. Hence, we can say that they are quite efficient theoretical tools that display constitutive creativity.

\footnotetext{
$\overline{12}$ In 2009, van Inwagen (2009, pp. 259-262) proffered a more informal version of the consequence argument.
} 
So far, I have illustrated constitutive creativity by analyzing philosophical arguments. The following section demonstrates the notion of depictive creativity by reviewing other work in the literature of philosophy.

\section{Depictive creativity illustrated}

In illustrating depictive creativity in practice, I would like to introduce an interesting thought experiment in the realm of the philosophy of mind. In one of his influential papers, Frank Jackson (1982) raised a question against physicalism about knowledge. The version of physicalism that he discussed was that all we can know is the knowledge of physical objects and their properties discoverable through natural science. According to this view, even knowledge of our mind and mental states is entirely constituted by physical facts. Jackson characterized physicalism as the view that "all (correct) information is physical information", where physical information is the information that "the physical, chemical and biological sciences have provided [...] about the world we live in and about ourselves" and the "information that automatically comes along with it" (1982, p. 127).

To reject physicalism of this kind, he presented what he called the knowledge argument. This argument features a striking story of a person who has been locked in a monochromatic environment for her entire life. The story goes as follows:
"Mary is a brilliant scientist who is, for whatever reason, forced to investigate the world from a black and white room via a black and white television monitor. She spe- cialises in the neurophysiology of vision and acquires, let us suppose, all the physical information there is to obtain about what goes on when we see ripe tomatoes, or the sky, and use terms like 'red', 'blue', and so on. [...] What will happen when Mary is released from her black and white room [...]? Will she learn anything or not? It seems just obvious that she will learn something about the world and our visual experience of it" (Jackson, 1982, p. 130).

The fact that Mary learns something when she gets out of the room implies that there is something she did not know about color vision when she was in the room. Since, by hypothesis, she is supposed to know all the physical knowledge about color vision, it follows that what she learns when she finally leaves the room is something other than a piece of physical knowledge. We can articulate this argument as follows:

Premise 1. In the black-and-white room, Mary knew all the physical knowledge about color vision.

Premise 2. When Mary goes outside for the first time, she obtains new knowledge about color vision.

Sub-conclusion. Mary did not know all there is to know about color vision when she was in the black-and-white room.

Conclusion. Physicalism about knowledge is false. ${ }^{13}$

\footnotetext{
${ }^{13}$ Jackson later clarified the knowledge argument and replied to some objections to it (1986, for some of the notable critiques of the knowledge argument see Lewis, 1983a, 1983b, 1999; Nemirow, 2007; Loar, 2002). Lewis (1983a, 1983b, 1999) and Laurence Nemirow (2007) contended that when Mary leaves the room, what she obtains is not a piece of factual knowledge but a cluster of abilities to recognize or remember colors. Brian Loar (2002) argued that though Mary obtains factual knowledge after her release, this is knowledge of an old fact seen in a different guise.
} 
To see how depictive creativity is employed in this argument, let us consider how the story of Mary is structured. The basic idea of the argument is that the qualitative aspect or "raw feels" of experiences - this is what is known as qualia in philosophical jargon - does not quite belong to the realm of physical knowledge. In Jackson's own terms, "there are certain features of $[. .$.$] perceptual experiences, which no amount of purely physical information$ includes" (1982, p. 127). Note that Mary is described as a person who lacks the experience of, though has the ability of, seeing colors. This characterization is pertinent to support the desired conclusion since Mary did not quite acquire qualia-related knowledge - i.e., the knowledge of how the world looks in color - when she was in the black-and-white room.

The story of Mary illustrates the main claim of the argument quite dramatically. By picturing Mary leaving the room, we envisage the excitement and wonder in appreciating the optical beauty provided by the world that she would be experiencing for the first time in her life. We are all familiar with what it is like to see colors and can tell how marvelous it would be for a person who has been forced to be confined to a monochromatic environment to see the world in color for the first time. ${ }^{14}$ This sort of familiarity, which is incorporated in the narrative of the thought experiment, contributes to strengthening the argument.

Notably, Mary's character pertinent to the purpose of the argument is quite vividly described. For instance, to describe how Mary specializes in color vision, Jackson wrote,

"[s]he discovers, for example, just which wave-length combinations from the sky stimulate the retina, and exactly how this produces via the central nervous system the contraction of the vocal chords and expulsion of air from the lungs that results in the uttering of the sentence "The sky is blue"' (1982, p. 130).

By offering the details, Jackson enabled readers to see how one is thought to have all the physical knowledge about color vision without ever seeing colors. ${ }^{15}$ From these observations, we can see how depictive creativity is demonstrated in Jackson's presentation of the knowledge argument. To further illustrate depictive creativity, I turn to another argument in the literature of ethics.

In an extremely influential work, Judith Jarvis Thomson proffered a story - commonly known as the violinist case - for the permissibility of abortion when pregnancy results from a forced sexual assault:

"You wake up in the morning and find yourself back to back in bed with an unconscious violinist. [...] He has been found to have a fatal kidney ailment, and the Society of Music Lovers has canvassed all the available medical records and found that you alone have the right blood type to help. They have therefore kidnapped you, and last night the violinist's circulatory system was plugged into yours, so that your kidneys can be used to extract poisons from his blood as well as your own. The director of the hospital now tells you, "Look, we're sorry the Society of Music Lovers did this to you [...] But [...] it's only for nine months. By then he will have recovered from his ailment, and can safely be unplugged from you" (1971, pp. 24-25).

\footnotetext{
${ }^{14}$ Or, perhaps, she may be confused or disturbed. In any case, the narrative of the example can invite us to imagine the intense whirl of emotions - positive or negative - Mary might feel when she sees colors for the first time.

${ }^{15}$ Jackson's argument does not suggest that there can possibly exist an individual like Mary in this world. Clearly, reality is not the issue here. The point is that even a being with complete physical knowledge of color vision would lack qualia-related knowledge.
} 
Here, Thomson cleverly drew an analogy between a rape victim who is pregnant with an unwanted life and a person forcibly linked to a stranger. Just as the rape victim is forced to carry the fetus against her will, the unfortunate protagonist of the violinist case suffers violence from the Society of Music Lovers to the effect that he/she ends up being stuck to an unwanted stranger attached to his/her back. If we employ the standard scheme of an argument from analogy, Thomson's argument can be represented in the following fashion:

Premise 1. You, the protagonist of the violinist case, are analogous to a pregnant

woman who is victimized by rape.

Premise 2. It is permissible for you to unplug yourself from the violinist.

Conclusion. So, it is permissible for the rape victim to abort the fetus.

As an instance of an argument from analogy, the success of this argument depends on how strongly it establishes the bond between the violinist case and pregnancy due to rape in developing the narrative of the violinist case ${ }^{16}$ and how convincingly it supports the permissibility of eliminating the attachment in the violinist case. ${ }^{17}$ The narrative of the violinist case fits to meet these conditions. Let us first note that in the preceding argument, the two supposedly analogous characters - namely, you and the rape victim - are claimed to share a particular property - namely, permissibly eliminating an unwanted dependent. To make a strong analogy, one needs to suggest a story analogous to its counterpart in a certain respect pertinent to this property. ${ }^{18}$ In the violinist case, Thomson presented a story analogous to pregnancy due to rape in the sense that in both cases, the victim finds himself/herself in a situation where he/she is attached to an unwanted dependent. This point is quite relevant to the property at hand, since the fact that he/she is forced to be confined to the dependent against his/her will gives a prima facie reason for him/her to be permissibly free of the dependent (or so goes the argument). ${ }^{19}$

Notably, Thomson created the narrative such that it suitably serves her purpose of defending abortion after rape. In the violinist case, the dependent is characterized as a stranger to the victim. Hence, the protagonist of the violinist case is stripped of the emotional bond a pregnant mother may have with her fetus. Furthermore, putting ourselves in the protagonist's shoe, we are led to judge how outrageous it must have been for one to be forcibly attached to a stranger. This maneuver makes the narrative of the violinist case appealing to those of us who have never experienced the ordeal of being pregnant - not to mention, the ordeal of living as a rape victim.

\footnotetext{
${ }^{16}$ The literature on Thomson's violinist case is huge. Relatively recent work includes the works of John Martin Fischer (2013) and Matthew Lu (2013). Fischer (2013) argued that the protagonist of the story has the obligation not to be unplugged from the violinist; but, since there is a significant moral difference between the violinist case and the pregnancy due to rape, this conclusion does not have any implication about the permissibility of rape-related abortion. Lu (2013) also argued that there is an important dis-analogy between the two cases while claiming that Thomson's argument is based on a mistaken picture of self-ownership of the body.

${ }^{17}$ These two tasks justify the first and second premises in the preceding representation of the argument, respectively. As mentioned earlier, I take no stand on the soundness of the arguments discussed in this paper, including this one.

${ }^{18}$ The standard scheme of an argument from analogy may be represented as follows: A is analogous to B with a certain respect $\mathrm{R}$; $\mathrm{B}$ has a certain property $\mathrm{P}$; therefore, $\mathrm{A}$ has $\mathrm{P}$ as well. Whether $\mathrm{R}$ is relevant to $\mathrm{P}$ is an important criterion in evaluating the argument. In other words, the argument is strengthened if $\mathrm{R}$ is relevant to $\mathrm{P}$.

${ }^{19}$ This, of course, is not to say that there is a decisive reason to think that the victim may permissibly eliminate the dependent. If there are stronger reasons to think otherwise, this prima facie reason can be overridden.
} 
Depictive creativity may also be said to be present in the extraordinary details of the story. For instance, by enabling us to evoke the image of one individual attached to another backto-back, the narrative of the violinist case leaves a quite impressive visual mark on our mind. Such an unusual circumstance, perhaps ironically, may help increase the memorability of the argument. As a highly intriguing story, Thomson's violinist case delivers a great example of depictive creativity embodied in philosophical work.

\section{Conclusions}

So far, I expounded the notions of constitutive and depictive creativities and how they are embodied in philosophy while analyzing several influential works. I noted that constitutive creativity concerns the theoretical constituents of a given argument, whereas depictive creativity pertains to its demonstration. Though I have described the two types of creativities separately, I do not mean to suggest that they are mutually exclusive. In fact, they are often intertwined. For example, after considering that I can be with the Evil Genius in some possible world, we can see that the character of the Evil Genius is cleverly drafted to suggest that all properties characteristic of a body may be separated from the veritability of experience. Hence, a reflection on Descartes's Evil Genius thought experiment may reveal that constitutive and depictive creativities are adequately incorporated in the conceivability argument. ${ }^{20}$

Finally, I would like to add that the ability to apply critical thinking plays a crucial role in developing the two types of creativities. We have seen that well-crafted theoretical tools such as the operator $N$ and inference rules $(\alpha)$ and $(\beta)$ in van Inwagen's consequence argument are the results of critical endeavor. We also noted that cardinal rules of logic such as Leibniz' law and the analyses of central concepts such as essentiality and determinism are used to establish the arguments we previously discussed. Furthermore, a critical examination of a philosophical view facilitates the creation of narratives suitable to support the arguments for it. For instance, after understanding the seminal idea behind Jackson's knowledge argument (namely, qualia-related knowledge does not belong to the realm of physical knowledge), one is apt to generate a story containing a character who knows every physical aspects of a subject matter but completely lacks qualitative experience of it. In other words, the proper analysis of physicalism helps create a character like Mary in the black-and-white room. Similarly, as we can see from our discussion of Thomson's argument, analyzing the distinctive features of pregnancy that stems from forced sex furthers the production of a narrative of an analogous character (namely, a person who is forced to be attached to, and let his/her kidney be used by, an unwanted stranger for nine months). In all of these examples, an ability to employ critical reasoning forms a solid foundation for constitutive and depictive creativities. In sum, critical thinking is effective both in constructing theoretical apparatuses viable to establish a given argument and in creating examples or narratives that facilitate the argument.

\footnotetext{
20 The same applies to Nozick's experience machine example. Just as the Evil Genius thought experiment enacts the scenario wherein one is stripped of all the bodily properties is perfectly conceivable, Nozick's example suits its purpose: it leads us to see how we prefer veritable experiences to unveritable ones. Here again, Nozick's story illustrates that the two types of creativities can be interlaced in a philosophical work.
} 


\section{Ackowledgements}

I am grateful to Seungbae Park for helpful discussion.

This work was supported by the Ministry of Education of the Republic of Korea and the National Research Foundation of Korea (NRF-2016S1A5A2A01024850).

\section{References}

Amabile, T. M. (1996). Creativity in context: update to the social psychology of creativity. Boulder, CO: Westview Press.

Baer, J. (2010). Is creativity domain specific?. In J. C. Kaufman \& R. J. Sternberg (Eds.), The Cambridge handbook of creativity (pp. 321-341). Cambridge: Cambridge University Press. https://doi.org/10.1017/CBO9780511763205.021

Baumeister, R. F., Schmeichel, B. J., \& DeWall, C. N. (2014). Creativity and consciousness: evidence from psychology experiments. In E. S. Paul \& S. B. Kaufman (Eds.), The philosophy of creativity: New essays (pp. 185-198). Oxford: Oxford University Press. https://doi.org/10.1093/acprof:oso/9780199836963.003.0010

Boden, M. A. (2004). The creative mind: myths and mechanisms. London and New York: Routledge.

Boden, M. A. (2014). Creativity and artificial intelligence: A contradiction in terms?. In E. S. Paul \& S. B. Kaufman (Eds.), The philosophy of creativity: New essays (pp. 224-245). Oxford: Oxford University Press. https://doi.org/10.1093/acprof:oso/9780199836963.003.0012

Briskman, L. (2009). Creative product and creative process in science and art. In M. Krausz, D. Dutton, \& K. Bardsley (Eds.), The idea of creativity (Vol. 28, pp. 17-42). Series: Philosophy of history and culture. M. Krausz (Series Ed.). Leiden, Boston: Brill. https://doi.org/10.1163/ej.9789004174443.i-348.12

Campbell, D. T. (1960). Blind variation and selective retentions in creative thought as in other knowledge processes. Psychological Review, 67(6), 380-400. https://doi.org/10.1037/h0040373

Carlson, E. (2000). Incompatibilism and the transfer of power necessity. Noûs, 34(2), 277-290. https://doi.org/10.1111/0029-4624.00211

Cropley, D., \& Cropley, A. (2010). Functional creativity: "Products" and the generation of effective novelty. In J. C. Kaufman \& R. J. Sternberg (Eds.), The Cambridge handbook of creativity (pp. 301-319). Cambridge: Cambridge University Press. https://doi.org/10.1017/CBO9780511763205.019

Descartes, R. (1984). Meditations on first philosophy. In The philosophical writings of descartes (Vol. II, pp. 12-62). Cambridge: Cambridge University Press.

Dutton, D. (2001). What Is Genius?. Philosophy and Literature, 25(1), 181-196. https://doi.org/10.1353/phl.2001.0005

Elster, J. (2000). Ulysses unbound: Studies in rationality, precommitment, and constraints. Cambridge: Cambridge University Press. https://doi.org/10.1017/CBO9780511625008

Feist, G. J. (2002). The influence of personality on artistic and scientific creativity. In R. J. Sternberg (Ed.), Handbook of creativity (pp. 273-296). Cambridge: Cambridge University Press.

Feist, G. J. (2010). The function of personality in creativity: The nature and nurture of the creative personality. In J. C. Kaufman \& R. J. Sternberg (Eds.), The Cambridge handbook of creativity (pp. 113130). Cambridge: Cambridge University Press. https://doi.org/10.1017/CBO9780511763205.009

Fischer, J. M. (2013). Abortion and Ownership. The Journal of Ethics, 17(4), 275-304.

https://doi.org/10.1007/s10892-013-9152-z 
Gabora, L., \& Kaufman, S. B. (2010). Evolutionary Approaches to Creativity. In J. C. Kaufman \& R. J. Sternberg (Eds.), The Cambridge handbook of creativity (pp. 279-300). Cambridge: Cambridge University Press. https://doi.org/10.1017/CBO9780511763205.018

Gaut, B. (2010). The philosophy of creativity. Philosophy Compass, 5(12), 1034-1046. https://doi.org/10.1111/j.1747-9991.2010.00351.x

Gaut, B., \& Livingston, P. (2003). Introduction: The creation of art: Issues and perspectives. In B. Gaut \& P. Livingston (Eds.), The creation of art: New essays in philosophical aesthetics (pp. 1-32). Cambridge: Cambridge University Press.

Jackson, F. (1982). Epiphenomenal Qualia. Philosophical Quarterly, 32(127), 127-136. https://doi.org/10.2307/2960077

Jackson, F. (1986). What Mary Didn’t Know. The Journal of Philosophy, 83(5), 291-295. https://doi.org/10.2307/2026143

Kant, I. (2000). Critique of the power of judgment. P. Guyer (Ed.). Series: The Cambridge edition of the works of Immanuel Kant. P. Guyer \& A. W. Wood (General Eds.). Cambridge: Cambridge University Press. https://doi.org/10.1017/CBO9780511804656

Kaufman, A. B., Kornilov, S. A., Bristol, A. S., Tan, M., \& Grigorenko, E. L. (2010). The neurobiological foundation of creative cognition. In J. C. Kaufman \& R. J. Sternberg (Eds.), The Cambridge handbook of creativity (pp. 216-232). Cambridge: Cambridge University Press. https://doi.org/10.1017/CBO9780511763205.014

Kripke, S. A. (1980). Naming and necessity. Cambridge, Massachusetts: Harvard University Press.

Leddy, Th. (1990). Is the creative process in art a form of puzzle solving?. The Journal of Aesthetic Education, 24(3), 83-97. https://doi.org/10.2307/3332801

Lewis, D. (1983a). Mad Pain and Martian Pain. In D. Lewis, Philosophical papers (Vol. I, pp. 122-129). New York, Oxford: Oxford University Press.

Lewis, D. (1983b). Postscript to "Mad Pain and Martian Pain". In D. Lewis, Philosophical papers (Vol. I, pp. 130-132). New York, Oxford: Oxford University Press.

Lewis, D. (1999). What experience teaches. In Papers in metaphysics and epistemology (pp. 262-290). Series: Cambridge Studies in Philosophy. Cambridge: Cambridge University Press. https://doi.org/10.1017/CBO9780511625343.018

Lewis, D. (2003). On the plurality of worlds. Malden: Blackwell Publishing.

Loar, B. (2002). Phenomenal states (Second Version). In D. J. Chalmers (Ed.), The philosophy of mind: Classical and contemporary readings (pp. 295-311). Oxford: Oxford University Press.

Locher, P. J. (2010). How does a visual artist create an artwork?. In J. C. Kaufman \& R. J. Sternberg (Eds.), The Cambridge handbook of creativity (pp. 131-144). Cambridge: Cambridge University Press. https://doi.org/10.1017/CBO9780511763205.010

Lu, M. (2013). Defusing Thomson's Violinist Analogy. Human Life Review, 39(1), 46-62.

Lubart, T. (2010). Cross-cultural perspectives on creativity. In J. C. Kaufman \& R. J. Sternberg (Eds.), The Cambridge handbook of creativity (pp. 265-278). Cambridge: Cambridge University Press. https://doi.org/10.1017/CBO9780511763205.017

McKay, Th. J, \& Johnson, D. (1996). A Reconsideration of an argument against compatibilism. Philosophical Topics, 24(2), 113-122. https://doi.org/10.5840/philtopics199624219

Nemirow, L. (2007). So this is what it's like: A defense of the ability hypothesis. In T. Alter \& S. Walter (Eds.), Phenomenal concepts and phenomenal knowledge: New essays on consciousness and physicalism (pp. 32-51). Oxford: Oxford University Press. https://doi.org/10.1093/acprof:oso/9780195171655.003.0002

Novitz, D. (1999). Creativity and constraint. Australasian Journal of Philosophy, 77(1), 67-82. https://doi.org/10.1080/00048409912348811 
Nozick, R. (1974). Anarchy, state, and utopia. New York: Basic Books.

Paul, E. S., \& Kaufman, S. B. (2014). Introducing the Philosophy of Creativity. In E. S. Paul \& S. B. Kaufman (Eds.), The Philosophy of Creativity: New Essays (pp. 3-15). Oxford: Oxford University Press. https://doi.org/10.1093/acprof:oso/9780199836963.001.0001

Picciuto, E., \& Carruthers, P. (2014). The origins of creativity. In E. S. Paul \& S. B. Kaufman (Eds.), The philosophy of creativity: New Essays (pp. 199-223). Oxford: Oxford University Press. https://doi.org/10.1093/acprof:oso/9780199836963.003.0011

Puccio, G. J., \& Cabra, J. F. (2010). Organizational creativity: A systems approach. In J. C. Kaufman \& R. J. Sternberg (Eds.), The Cambridge handbook of creativity (pp. 145-173). Cambridge: Cambridge University Press. https://doi.org/10.1017/CBO9780511763205.011

Richards, R. (2010). Everyday creativity: Process and way of life - four key issues. In J. C. Kaufman \& R. J. Sternberg (Eds.), The Cambridge handbook of creativity (pp. 189-215). Cambridge: Cambridge University Press. https://doi.org/10.1017/CBO9780511763205.013

Runco, M. A. (2010). Parsimonious creativity and its measurement. In E. Villalba (Ed.), Measuring creativity: Proceedings for the Conference, "Can Creativity Be Measured?" (pp. 393-406). Brussels, May 28-29, 2009. Luxembourg City: Publications Office of the European Union.

Russ, S. W., \& Fiorelli, J. A. (2010). Developmental approaches to creativity. In J. C. Kaufman \& R. J. Sternberg (Eds.), The Cambridge handbook of creativity (pp. 233-249). Cambridge: Cambridge University Press. https://doi.org/10.1017/CBO9780511763205.015

Sawyer, R. K. (2012). Explaining creativity: The science of human innovation. Oxford: Oxford University Press.

Searle, J. R. (1980). Minds, brain, and programs. The Behavioral and Brain Sciences, 3(3), 417-457. https://doi.org/10.1017/S0140525X00005756

Simonton, D. K. 1999. Origins of genius: Darwinian perspectives on creativity. New York, Oxford: Oxford University Press.

Simonton, D. K. (2009). Creativity as a Darwinian phenomenon: The blind-variation and selectiveretention model. In M. Krausz, D. Dutton, \& K. Bardsley (Eds.), The idea of creativity (Vol. 28, pp. 63-82). Series: Philosophy of history and culture. M. Krausz (Series Ed.). Leiden, Boston: Brill.

Simonton, D. K. (2010). Creativity in highly eminent individuals. In J. C. Kaufman \& R. J. Sternberg (Eds.), The Cambridge handbook of creativity (pp. 174-188). Cambridge: Cambridge University Press. https://doi.org/10.1017/CBO9780511763205.012

Smith, J. K., \& Smith, L. F. (2010). Educational creativity. In J. C. Kaufman \& R. J. Sternberg (Eds.), The Cambridge handbook of creativity (pp. 250-264). Cambridge: Cambridge University Press. https://doi.org/10.1017/CBO9780511763205.016

Stokes, D. (2011). Minimally creative thought. Metaphilosophy, 42(5), 658-681. https://doi.org/10.1111/j.1467-9973.2011.01716.x

Thomson, J. J. (1971). A defense of abortion. Philosophy \& Public Affairs, 1(1), 47-66. https://doi.org/10.1007/978-1-4615-6561-1_6

van Inwagen, P. (1983). An essay on free will. Oxford: Clarendon Press.

van Inwagen, P. (2000). Free will remains a mystery. In J. E. Tomberlin (Ed.), Philosophical Perspectives (Vol. 14, pp. 1-19). Action and Freedom. Malden: Blackwell Publishers, Inc.

van Inwagen, P. (2009). Metaphysics. Boulder: Westview Press.

Ward, Th. B., \& Kolomyts, Yu. (2010). Cognition and creativity. In J. C. Kaufman \& R. J. Sternberg (Eds.), The Cambridge handbook of creativity (pp. 93-112). Cambridge: Cambridge University Press. https://doi.org/10.1017/CBO9780511763205.008

Weisberg, R. W. (2006). Creativity: Understanding innovation in problem solving, science, invention, and the arts. Hoboken, New Jersey: John Wiley \& Sons, Inc.

Widerker, D. (1987). On an Argument for Incompatibilism. Analysis, 47(1), 37-41. https://doi.org/10.1093/analys/47.1.37 


\title{
STEIGIAMASIS IR APRAŠOMASIS KŪRYBIŠKUMAS FILOSOFIJOJE IR KRITINIAME MĄSTYME
}

\author{
Huiyuhl YI
}

\section{Santrauka}

Šiame straipsnyje, tyrinejjant kai kuriuos svarbius filosofinius požiūrius ir minties eksperimentus, pristatomi du kūrybiškumo tipai filosofijoje: steigiamasis kūrybiškumas ir aprašomasis kūrybiškumas. Steigiamasis kūrybiškumas nurodo gebėjimus, reikalingus teorinèms reikmėms ir priemonèms konstruoti, būtinoms tam tikros filosofinès minties branduoliui suformuoti. Steigiamąji kūrybiškumą galima įvertinti teorinių įrankių, kurie pasitelkiami tikslinès idèjos atžvilgiu, tinkamumo požiūriu. Steigiamojo kūrybiškumo formavimas dažnai siejamas su aprašomuoju kūrybiškumu. Aprašomasis kūrybiškumas nurodo gebėjimus remtis svariais pavyzdžiais ar kurti naratyvus, sustiprinančius duotuoju momentu svarstomą klausimą. Aprašomojo kūrybiškumo vertinimai priklauso nuo pavyzdžių ar pasakojimų išradingumo tiek, kiek jie tiesiogiai prisideda prie norimos išvados gavimo. Aiškindamas steigiamojo ir aprašomojo kūrybiškumo sąvokas bei nagrinėdamas kai kuriuos filosofinès literatūros pavyzdžius, pabrèžiu, kad kritinis mąstymas apvainikuoja galimai formuojamą abiejų tipų kūrybiškumą.

Reikšminiai žodžiai: suvokiamumo argumentas, padarinio argumentas, steigiamasis kūrybiškumas, aprašomasis kūrybiškumas, žinojimo argumentas, smuikininko atvejis. 